\title{
An Empirical Investigation of the Determinants of Foreign Exchange in Nigeria.
}

\author{
Harley Tega Williams \\ Redeemer's University, Ede, Osun State, Nigeria. \\ Adegbola Dare \\ Redeemer's University, Ede Osun State, Nigeria. \\ Afolabi Taofeek Sola \\ Redeemer's University, Ede, Osun State, Nigeria.
}

\begin{abstract}
The determinants of foreign exchange rate was carried out using time series data from 1986 to 2016.This analysis attempted to find out the casual relationship between external reserves and foreign exchange rate in the Nigerian context by looking at the impact of foreign exchange rate on external reserves from 1986 to 2016 and after the financial crisis. The Nigeria economy is a mono economy where the import is stronger than export making the Nigeria naira irrelevant in the global market. This prompted the researchers to undertake this study so as to establish a linear relationship between external reserves and other variables likely to affect foreign exchange rate. The theoretical framework of production and risk aversion and model specification variables applied in this study may have been overlooked by previous studies. The study found out that the Nigerian external reserves $(R S=0.000139)$ positively affect foreign exchange rate in a normal economic situation and negatively affect foreign exchange rate in a period of global financial crisis. In the period of global financial crisis, the study recommends that the Nigeria government can increase her export to strengthen her currency so as to make her currency globally competitive. Furthermore, the external reserve is just a backup plan to cushion the effect of financial crisis and international liability in terms of balance of payment problem not as a core determinant of foreign exchange rate in Nigeria.
\end{abstract}

Keywords: external reserves, foreign exchange rate, financial crisis, risk aversion, export.

\section{INTRODUCTION}

Foreign exchange rate reserves are affected by policies adopted by a nation's central bank or monetary authority. A nation may either adopt fixed, floating or mixed exchange rate regime. In the history of Nigeria, the floating, fixed and mixed exchange rate regimes have been adopted so as to safeguard the currency. Presently, Nigeria adopts the fixed exchange rate system which is adapted from the Bretton Woods system, therefore the need for reserves if a country adopt the fixed exchange rate system. Most central banks hold assets to pay liabilities or debts. These assets are held in one or more currencies. In Nigeria, reserves are held in the United States dollar and they can be traced in the balance of payment accounts.

A general and clear comparisons between the fixed exchange rate and the floating exchange rate is the necessity for reserves; while the latter does not, the former does. The Nigerian economic system has a link with the fixed exchange rate and reserves but these relationship has been affected by political instabilities (military and civilian rules) which have deeply affected her currency. Gokhale \& Raju (2013) itemized some determinants factors that affect the exchange rate to be economic and non-economic factors such as capital inflows, inflation rate, interest rate, current account balance etc. As stated by Gokhale \& Raju (2013), nations 
maintained reserves to manage exchange rates and fluctuation costs in the international trade and settlement cost. However, the effect of fixed exchange rate policy is that there is a currency fluctuation due to the impact of the forces of demand and supply. Schumpeter (1911) stated that in the above scenario, demands lead and supply follows. The need for the study arise as a result of the conclusion of Gokhale \& Raju (2013) that reserves are not used to tame foreign exchange rate fluctuations but to fight against global financial crisis, as well as attracting foreign direct investments. Therefore, external reserves can be used to secure a position in international trade finance and for the prevention of foreign exchange rate fluctuation if the country adopts a fixed interest rate. After the fall of the Bretton Woods system in 1970, most countries adopt the flexible exchange rate system with some theories such as the signaling or vulnerability indicator theory, exchange rate policy etc. For more than four decades of study by scholars in the field of external reserves and foreign exchange rate and reserves modelling with risk aversion theory have not been on quantitative research in Nigeria. Scholars in this field of study had always adopted foreign exchange theories, but this study seeks other theories likely to play significant impact of foreign exchange rate and external reserves in Nigeria. Also, there had been no model to link foreign exchange rate, external reserves, inflation rate, interest rate, import and export with the theory of production and risk aversion on an ordinary least square regression. Given the foregoing, In spite of the importance of external reserves in Nigeria, foreign exchange rate and external reserve models have not been in the mainstream of quantitative researches in Nigeria. Research in Nigeria had looked at the impact of foreign exchange rate and external reserves with BDC rate on monthly data (Ngozi et al, 2016), the need for this study is to empirically investigate the determinants of foreign exchange rate in the Nigerian context using external reserves and other variables on a risk aversion and production theory. The uniqueness of this study is the application of variables and data used.

\section{LITERATURE REVIEW}

Lazarus A. (2017) stated that the General Electronics' \$1billion investment in Nigeria is to establish a footprint that will create value and provide jobs for Nigerians, support small and medium scale companies and ultimately help energize the local economy. He further explained that the exchange rate of the Nigerian naira is a challenging factor in the global market, as the naira to the dollar is very weak due to low level of international trade export and political instability.

However, Adegbite \& Ayadi (2011) cited by Owolabi (2017) stated that Nigeria has made little progress in attracting investment in previous decades compared to the current decade where the exchange rate of the dollar to naira is high. This might sound paradoxical since the country has traditionally been one of the biggest recipients of foreign investment inflows in Africa with large volumes of exchange rate transactions. However, when the Nigerian population is compared to the size of her economy, it becomes apparent that the amounts of investments into Nigeria are rather small, which presents a comparative analysis of the dollar to naira exchange rate or a percentage of gross fixed capital formation, investment stock and as a percentage of GDP, relative to South Africa where the currency is measurable to the dollar. To this effect, the context of the theoretical framework of this empirical study on the determinants of foreign exchange in Nigeria are broadly divided into "production flexibility" and "risk aversion" arguments. To understand the 'production flexibility', the work of Bourne et al (2003) stated that manufacturing remains a key issue for modern manufacturing system to attract relationship and currency through international trade. Georgoulias et al (2009) stated on a chart analysis that the business environment provides feedback effect from the left and from the right. The left feedback effect is on production performance and the right feedback effect is on investment decision. However, a major strength of the production flexibility theory is that 
the theory speculates a linear relationship between the parts that makes up the structure. This may means that increase or decrease in a particular part may positively or negatively affect the other part. For countries like the United States, Japan and China to remain in business and to attract more foreign exchange to herself, its firms must make effort to remain highly competitive and also increase responsiveness to demand of goods from other countries. Daud and Ahmad (2013) stated conclusively that for firms and nations to remain successful in sales and foreign exchange attraction in a globally competitive market, they must fulfil the flexibility and assessment capabilities, integration of flexibility evaluation tools with production monitoring. To this effect, a country that is involved in foreign exchange transactions will create opportunity to experience faster growth and development compared to the nations that do not create opportunity for foreign exchange. Based on the foregoing discussion, international trade and production in Nigeria have the prospect of making the Nigerian economy to experience frequent foreign exchange transactions that will contribute to the country's wealth only if the right framework (production flexibility theory) are made use of by all stakeholders in Nigeria.

An alternative approach linking exchange-rate variability and investment relies on the risk aversion theory. The logic is that investors require compensation for risks that exchange rate movements introduce additional risk into the returns on investment. Higher exchange-rate variability lowers the certainty equivalent expected of exchange-rate level, as in Cushman (1988). Since certainty equivalent levels are used in the expected profit functions of firms that make investment decisions today in order to realize profits in future periods. If exchange rates are highly volatile, the expected values of investment projects are reduced, and the FDI is reduced accordingly. Risk aversion therefore is the responsiveness or the behaviour of man to risk. In today's world, the foreign exchange market is the largest market in the world. The foreign exchange market is not a physical place where buyers and sellers are expected to see each other and guarantee a fair business deal. Based on human nature, human beings tend to be certain on what they can see rather than what cannot be seen. Therefore, the risk in the foreign exchange market is higher than that of any other market. Therefore, in our perspective, the implication of this theoretical framework to the determinants of foreign exchange in Nigeria is that where there is a market, there is risk hence risk cannot be isolated from a market. The foreign exchange market poses a very high risk, hence investors and nations that deals in foreign exchange has no perfect information of the market but can create a strategy to outguess the market. 
Figure 1.2: Theoretical Modelling of the Study

THEORY

INDEPENDENT VARIABLES

DEPENDENT VARIABLE

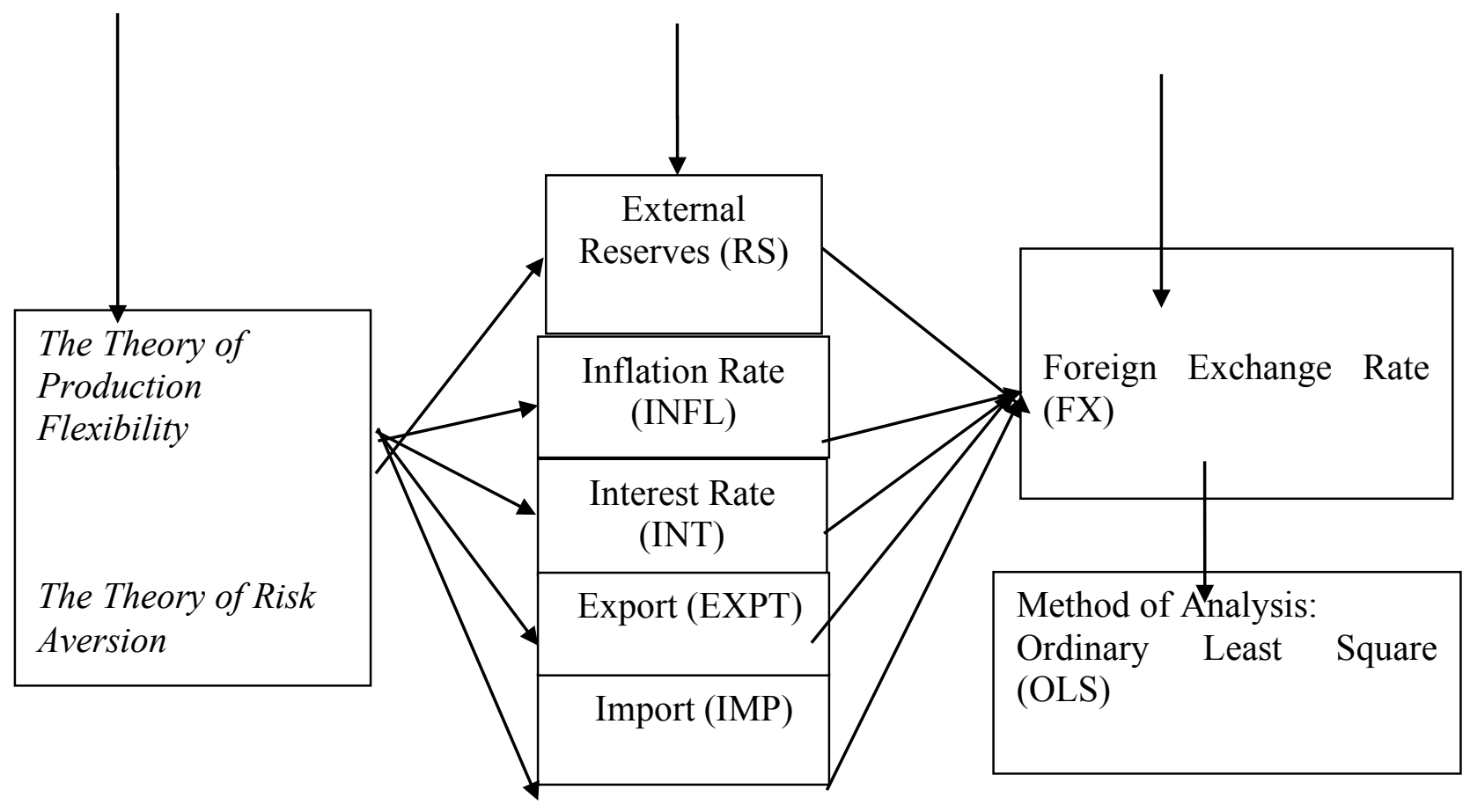

Source: Researchers 2018.

\section{Empirical Review}

Varied results have been found on the effect of foreign exchange rates on reserves. Some literatures found a positive effect, why some studies show no effect and others found a negative effect. Many nations have developed strategies to maintain and manage reserves so as to cushion foreign exchange rate fluctuations and adjust any cost in international trades that is associated with fluctuations. Many developing nations that are not core players in the foreign exchange market maintain high reserves in their custody to cushion any negative effect from any uncertainty in the foreign exchange market. Having noted the relevance of foreign exchange reserves, Aizenmann \& Lee (2005) stated that reserves stand as a tool for maintaining lower exchange rate to promote trade and international competitiveness. Dooley et al (2004) stated that the Asian Central Bank's accumulation of reserves is to prevent currency from appreciation against dollar to promote export led growth.

Different scholars across the globe have come out with different statistical and econometric models to check the impacts of foreign exchange rate on reserves and vice versa. Gokhale \& Raju (2013) investigated exchange rate and foreign exchange reserves in Indian. They found out that a high level of foreign exchange reserves may not show a long or short run correlation with exchange rate. Comparing the work of Gokhale \& Raju (2013) and the work of Yousaf et al. (2013) and Eliza (2008), which examines the impact of exchange rates on FDI in Pakistan, we can deduce that Yousaf et al (2013) and Ellahi (2011) uses FDI as a core variable to answer the research question while Gokhale \& Raju (2013) uses foreign exchange reserves to answer the research question. Foad (2005) stated that nations whose risk is high in terms of foreign exchange will lose more foreign direct investments. This corroborates and affirms the reason why Yousaf et al (2013) and Ellahi (2011) considered the FDI as a factor of foreign exchange determinants. A direct investment in a country with a high degree of exchange rate fluctuations will have a more risky stream of profits. As long as this investment is partially irreversible, there is some positive value to holding off on this investment to acquire more information (the risk averse theory). 
Osinubi \& Amaghioyeodiwe (2009) identified Nigeria as one of the countries with a high degree of currency risk. The authors empirically investigated the effects of exchange rate on Foreign Direct Investment (FDI) in Nigeria, using secondary time series data from 1970 to 2004.

Kiru (2016) looked at the effect of exchange rate volatility on the Zambian Stock Market from 2000 to 2015 and found out that there is a negative relationship between the exchange rate and the stock. The work of Kiru (2016) does not corroborate with the definition of reserves used for hedging as stated by the International Monetary Fund. The fall of the Bretton Woods system and the importance of external reserves, the Central Bank of Nigeria Act of 1991 empowered the Central Bank of Nigeria (CBN) to safeguard her currency from any negative impact of foreign exchange as well as to provide confidence in her local currency. CBN (2017) stated that the Nigerian external reserves has been fluctuating in its movement but in the first half of 2017 , there is $16 \%$ increase in foreign reserves which stands at $\$ 30.271$ billion as at June 29, 2017.

Tariq et al (2014) stated that most developing nations often feel the negative effect of real exchange rate volatility and thus reduce the development of their economic growth. Dooley et al (2004) stated that when nations hold reserves, it stands a form of mechanism to facilitate growth and maintain undervalued real exchange rate. Dooley et al (2004) stated this in the context of China. Romero (2005) investigated a study that deals with a comparative analysis of the factors of international reserves demands in China and India. The study applied a fixed exchange rate model based on sample period for the former and a floating exchange rate based sample period for the latter country by using an annual data for the period 1980 to 2003 . The study concluded that there was no relationship of fixed and floating exchange rate with reserves. However, it was noted that the data, such as current account balance, average propensity to import, and real exchange rate has equilibrium relationship. Eliza et al (2008) uses Malaysian data from 1970 to 2004 to study if there is a short or long-run demand for international reserves. He uses an advanced econometrics method called the autoregressive distributed lag (ARDL) bounds testing approach. His results showed that the current account balance and short-term external debt significantly affect the demand for international reserves both in the long run and short run. Similarly, the work of Ahmad and Kyereboah-Coleman, A. and Agyire-Tettey, K.F. (2008) uses data from selected African countries for 34 years to examine the relationship between exchange rate and foreign reserves and relate it to the Ghana economy. They applied the co-integration method and found out that a long-run dynamics exist.

The review of the literature reveals the existence of many gaps of knowledge in respect of the determinants of foreign exchange rate, particularly in the context of Nigeria where some factors tends not to determine foreign exchange as compared to other developed nations. In the reviewed literatures, some of the empirical studies that have been conducted with the aim of identifying the impact of foreign exchange rate on reserves in some emerging markets include countries such as Pakistan and India. The literature also reveals the existence of controversial conclusions that result from different studies made so far. Furthermore, the review of some of the literature reveals that very scant work has been done with the research question and objective of identifying the impact of external reserves on foreign exchange rate in Nigeria. The findings of prior empirical studies provided varying evidence related to studies like the impact of foreign exchange rates on external reserves using advance econometrics analysis. Odili (2015) found the impact of exchange rate on investment in Nigeria using OLS methodology. His study shows that there is a negative significant relationship between 
exchange rate volatility and the inflow of investment. Ajibola et al (2015) investigated the impact of exchange rate and external reserves in Nigeria using time series data from 1990 to 2012 on a Threshold Vector Error Correction Model (TVECM) methodology. Their study found that there is a co-integration of variables if the equilibrium error is more than an estimated threshold parameter of 0.52 . Gokhale \& Raju (2013) also studied the causality between the exchange rate and foreign exchange reserves using Indian data and found that there is no short and long-term association between exchange rate and foreign exchange reserve in the Indian context. Romdhane (2015) studied the impact of exchange rate fluctuation on economic growth and found that there may either be positive or negative impact based on the volume of foreign direct investment.

Having noted all these as well as the empirical review, the idea behind this study is to look at the variable not included in the work of Gokhale \& Raju (2013) and to apply another form of research method on the Nigerian data and context. Nwachukwu et al (2016) looked at bureau de change rates and external reserves in Nigeria within 2014 to 2015 using econometric analysis and found that the error correction affect BDC exchange rate while Tariq et al (2014) used an empirical methodology known as the mercantilist method to find the relationship between the exchange rate and foreign exchange reserves from 1973 to 2008 in Pakistan. A careful study of these works shows that there is a vacuum in the context of Nigeria and the existence of knowledge gap in this area initiated this study. Therefore, to examine the impact of external reserves on foreign exchange rate in Nigeria while holding other determinants of foreign exchange rate constant and to fill the knowledge gap that exists in this area by adopting risk and production theory and export and import variables.

\section{RESEARCH METHODOLOGY}

In order to account for the determinants of foreign exchange in Nigeria, the Ordinary Least Square Regression Techniques was adopted. The model for the study is hereby specified as follows:

$$
\begin{aligned}
& \mathrm{FX}=\mathrm{f}(\mathrm{RS}, \mathrm{INT}, \mathrm{INFL}, \mathrm{IMP}, \mathrm{EXPT}) \\
& F X=B_{0}+B_{1} R S+B_{2} I N T+B_{3} I N F L+B_{4} I M P+B_{5} E X P T
\end{aligned}
$$

Where:

FX= Foreign Exchange Rate

RS= External Reserve

INFL= Inflation Rate

INT = Interest Rate

IMP = Import

EXPT $=$ Export

\section{Confirmation of OLS assumption}

Linear in parameter: The Shapiro Wiks Test makes it easy for the test for normality to be calculated. Shapiro uses kurtosis and standard error on data that is less than 50 observations. The scope of the study is from 1986 to 2016 which are 31 observations in all, hence the use of Shapiro Wilks test is appropriate in testing for normality. To test for normality, we need the value of kurtosis and standard error of all the variables specified in the model. The value for kurtosis can be obtained from the descriptive statistics shown in table 1.3 and the standard error can be computed using the general model regression result and scope of 1986-2016. The formular used in testing for normality is stated below:

Normality Test = kurtosis/standard error. 
Therefore, the test for normality of all the variables holds.

Table 1.3: Regression Result Table

Dependent Variable: FX

Method: Least Squares

Date: 04/15/18 Time: 12:21

Sample: 19862016

Included observations: 31

\begin{tabular}{crrrr}
\hline \hline \multicolumn{1}{c}{ Variable } & Coefficient & Std. Error & t-Statistic & Prob. \\
\hline \hline C & 18.67595 & 29.69971 & 0.628826 & 0.5352 \\
RS & 0.000139 & 0.000611 & 0.227445 & 0.8219 \\
INT & -2114.933 & 3948.234 & -0.535666 & 0.5969 \\
INFL & 116.2491 & 247.1133 & 0.470428 & 0.6421 \\
EXPT & 4.660005 & 1.350005 & 3.446024 & 0.0020 \\
EMP & -3.780005 & 1.280005 & -2.948564 & 0.0068 \\
\hline \hline & 0.813633 & Mean dependent var & 88.82697 \\
Adjusted R-squared & 0.776359 & S.D. dependent var & 70.29011 \\
S.E. of regression & 33.24065 & Akaike info criterion & 10.01741 \\
Sum squared resid & 27623.53 & Schwarz criterion & 10.29496 \\
Log likelihood & -149.2699 & Hannan-Quinn criter. & 10.10788 \\
F-statistic & 21.82876 & Durbin-Watson stat & 0.669818 \\
Prob. (F-statistic) & 0.000000 & & & \\
\hline \hline
\end{tabular}

Source: Eview output 2018

\section{Interpretation of Regression Results and Discussions (Table 1.3).}

Table 1.3 shows the regression result of the model from 1986 to 2016. The dependent variable is FX and the independent variables are RS, INT, INFL, IMP and EXPT. From the table above, there are positive and negative relations between the dependent variable and the independent variables. There is a positive relationship between RS (external reserves) and FX (foreign exchange rates) in Nigeria. One percent increase in RS of 0.000139 will lead to a corresponding increase in FX. This means that RS affect FX positively in this study. There is a negative relationship between Interest Rate (INT) and Foreign Exchange Rate (FX). A rise in INT will lead to a fall in FX of about -2114.933. This negative impact may be attributed to the global financial crisis that rocked the financial sector in the world in years 2008 and 2009. There is a positive relationship between Inflation Rate (INFL) and the Foreign Exchange Rate (FX). Some finance literatures prove that inflation has a negative impact on any dependent variable (Harley tega et al (2016). This positive relation of 116.2491 violates the a priori expectation. This means one percent increase on inflation rate of 116.2491 will lead to an increase in FX. The positive relationship between Import (IMP) and the Foreign Exchange Rate (FX) shows that Import attracts foreign exchange rate in Nigeria. One percent increase in the value of import of 4.66 will lead to a corresponding increase in the value of foreign exchange rate in Nigeria. There is a negative relationship between export (EXPT) and foreign exchange (FX) of 3.780. The coefficient of determination looks to be very high of $0.8136(81.36 \%)$ meaning that all the independent variables used in the study are explained by the FX model. The $\mathrm{R}^{2}$ adj shows $0.776(77.6 \%)$. The prob. (f-statistics) of 0.0000 show that the model of the study is statistically significant. The Durbin Watson statistics of 0.669818 is evaluated using the standard rule of $\mathrm{n}=31$ at $5 \%$ confidence interval, $\mathrm{k}=5$ excluding the constant from the model. Our $\mathrm{DU}=1.825$ and $\mathrm{DL}=1.090$ 
The conclusion of this result is that the null hypothesis should be rejected and that there is a serial correlation in the model.

\section{Test of Hypotheses}

The t-test value is assume to be the average weighted and can be used to test hypothesis. We assume that $\mathrm{T}$-tabulated is $5 \%(0.05)$.

We reject $\mathrm{H}_{0}$ if $\mathrm{T}$-calculated $>$ T-tabulated. T-calculated can be obtained from the regression table above.

\section{Hypothesis}

$\mathbf{H}_{\mathbf{o}}$ : Nigerian external reserves does not significantly affect foreign exchange rate

T-test is a statistical tool that gives a clear conclusion on the acceptance or rejection of the hypothesis. The variables to be tested are external reserves (RS) and the foreign exchange rate (FX) which is the central objective of this study. The RS calculated shows a value of 0.227445 which is compared to a sig. value of 0.05 .

$0.227445>0.05$.

We reject the null hypothesis and accept the alternative hypothesis that external reserves significantly affect the foreign exchange rate in Nigeria.

\section{Regression Result on Data 2006-2016 and the Effect of Global Financial Crisis on Foreign Exchange Rate and External Reserves (RS)}

Table 1.3.3

\begin{tabular}{|c|c|c|c|c|}
\hline \multicolumn{5}{|c|}{$\begin{array}{l}\text { Dependent Variable: FX } \\
\text { Method: Least Squares } \\
\text { Date: 04/28/18 Time: } 14: 22 \\
\text { Sample: } 20032016 \\
\text { Included observations: } 14\end{array}$} \\
\hline Variable & Coefficient & Std. Error & t-Statistic & Prob. \\
\hline $\mathrm{C}$ & 105.3859 & 22.71276 & 4.639946 & 0.0017 \\
\hline RS & -0.001065 & 0.000329 & -3.242463 & 0.0118 \\
\hline INT & 3868.104 & 2700.704 & 1.432258 & 0.1900 \\
\hline INFL & 226.6215 & 142.5274 & 1.590021 & 0.1505 \\
\hline IMP & 1.710005 & 5.880006 & 2.917434 & 0.0194 \\
\hline EXPT & -1.170005 & 5.500006 & -2.131646 & 0.0656 \\
\hline R-squared & 0.921052 & \multirow{7}{*}{\multicolumn{2}{|c|}{$\begin{array}{l}\text { Mean dependent var } \\
\text { S.D. dependent var } \\
\text { Akaike info criterion } \\
\text { Schwarz criterion } \\
\text { Hannan-Quinn criter. } \\
\text { Durbin-Watson stat }\end{array}$}} & 152.9450 \\
\hline Adjusted R-squared & 0.871710 & & & 34.75890 \\
\hline S.E. of regression & 12.44979 & & & 8.178812 \\
\hline Sum squared resid & 1239.979 & & & 8.452694 \\
\hline Log likelihood & -51.25169 & & & 8.153459 \\
\hline F-statistic & 18.66661 & & & 1.630137 \\
\hline Prob(F-statistic) & 0.000318 & & & \\
\hline
\end{tabular}

\section{Source: Eview 2018 output}

\section{Interpretation of Regression Result and Discussions.}

The objective of this regression result is to find the lacuna of the variables and compared with the general model regression result of the scope of the study so as to answer accurately the 
research questions and the test of hypothesis. The dependent variable is FX and the independent variables are RS, INT, INFL, IMP and EXPT. From the table 1.3.3 above, there are positive and negative relations between the dependent variable and the independent variables. In table 1.3.3 the relationship between external reserves and foreign exchange rate shows a negative relationship of -0.001065 . This negative relationship shows the impact of the global financial crisis that rocked the financial sectors and the economics of nations. A comparison of table 1.3.2 and table 1.3.3 shows that RS is positive and RS is negative respectively. Adegbite \& Ayadi (2011) stated that there were foreign direct investment decline in Nigeria due to global financial crisis, less developed nations like Nigeria had a slight reduction of her external reserves. Hemen et al (2014) stated that the financial crisis generally affected the trade and foreign exchange rates in Nigerian business transactions. Ngozi et al (2016) stated that the introduction of the Central Bank of Nigeria Bureau De Change (BDC) and the Dutch method of exchange and bidding system was a result of the decline in external reserves and the foreign exchange rate problem during the period of the global financial crisis. There is a positive relationship between Interest Rate (INT) and Foreign Exchange Rate (FX) of 3868.104. A rise in one unit of real INT rate will lead to a corresponding rise in FX of the same unit. However, the unstable nature of INT and FX may arise as a result of the impact of the global financial crisis. The inflation rate (INFL) shows a negative impact on (FX) on table 4.4.3 while there was a positive impact of inflation rate on $\mathrm{FX}$ as shown in table 1.3.2. The negative impact of inflation rate (INFL) on foreign exchange rate (FX) affirms the economics principle that INFL has negative impact on any dependent variable. This negative impact of inflation rate (INFL) of 226.6215 shows that one percent increase in INFL will lead to a fall in FX. The negative impact of INFL in this study is captured by the impact of the global financial crisis as stated by Hemen et al (2014). The export (EXPT) data still maintain negative relationship with FX in respective of the period. This shows that the Nigerian economy is lagging behind in terms of export when compared with that of other countries. However, the Nigerian low level of export weakens her currency exchange power and thus lowers her external reserves. The import (IMP) shows positive relationship with foreign exchange rate on table 1.3.2 and table 1.3.3 respectively. Nigerian economy had been known as an economy of import, the regression results corroborate other studies such as the study of Harleytega (2018) that the major source of income is on the export of crude oil which is sold back to Nigeria as refined oil on the exported price multiplied by two making import higher than export. Therefore, this study recommended functional refineries in Nigeria for the refining of crude oil to cut off the high price of refined oil that triggers foreign exchange rate and lower external reserves. The coefficient of determination is high; it shows that 0.921 (92.1\%) of the explanatory variables are captured by the model. In econometrics, the closer the coefficient of determination to one, the higher the good fit of the model.

\section{SUMMARY OF FINDINGS, CONCLUSION AND RECOMMENDATION}

Since the core objective of the study is to find out the determinants of foreign exchange rate in Nigeria using external reserves and other variables, the summary of the findings is hereby stated below:

There is a positive relationship between RS (external reserves) and FX (foreign exchange rates) in Nigeria from 1986 to 2016. In this case RS affect FX positively. In the period of financial crisis, the relationship between external reserves and foreign exchange rate shows a negative relationship. This negative relationship shows the impact of the global financial crisis shows the relevance of external reserves. 
A high inflation stands a discouragement to investors. When investors are discouraged, there is low level of investment which on the other hand weaken the country external reserves. It is noted that one of the reason why reserves is set up is to pay off debt and an increase in inflation erode the values of reserves. Inflation rate shows an average of 0.110000 . This is an equivalent of $11 \%$. The Nigeria inflation rate revolves round two digit number hence the inflation rate it clear impact as a determinant factor of foreign exchange rate in Nigeria. Therefore, one of the findings of this study is that the Nigerian inflation rate affect foreign exchange rate in Nigeria from 1986 to 2016.The INFL t-value of 1.590021 which is compared to a sig. value of $0.05 .1 .590021>0.05$. We reject the null hypothesis and accept the alternative hypothesis that inflation rate significantly affect the foreign exchange rate in Nigeria. Having noted the impact of the global financial crisis therefore, one of the findings of this study is that the Nigerian inflation rate affect foreign exchange rate in Nigeria. The decision corroborate with the general model used in this study and the universal determinants factors that inflation rate affect or is a determinants factor of foreign exchange rate.

The interest rate moves up wards and down wards within the period under study. This indicates that the interest rate looks like a random walk. Generally, prevailing interest rate has been noted to be a determinant factor of foreign exchange rate (Gokhale \& Raju 2013). This study adopts the real interest rate in Nigeria. The mean of the interest rate (INT) shows a negative of -0.00017 . The reason for this negative value may arise as a result of the fact that this study adopts the real interest rate which revolves between negative and positive values.

Balance of payment factor is a determinants of foreign exchange rate. A critical study shows that the civilian rule in Nigeria encourages importation of goods than the military. This is a confirmation that political instability affect foreign exchange rate in Nigeria. An outlier was discovered on import and export because the currency was in naira, this overcast the mean. Despite the global financial crisis in 2008 and 2009, the export value were not affected, there was no fall or rise in the value of export. The value of export therefore maintains a constant growth rate in Nigeria from 1986 to 2016.

The coefficient of determination looks to be very high at $0.8136(81.36 \%)$ meaning that all the independent variables used in the study are explained by the FX model. The $\mathrm{R}^{2}$ adj shows 0.776 (77.6\%). The prob. (f-statistics) of 0.0000 show that the model of the study is statistically significant. The Durbin Watson statistics of 0.669818 is evaluated using the standard rule of $\mathrm{n}=31$ at $5 \%$ confidence interval, $\mathrm{k}=5$ excluding the constant from the model. Our DU= 1.825 and $\mathrm{DL}=1.090 .0<\mathrm{DW}<\mathrm{DL}=0<0.669818<1.090$. The conclusion of this result is that the model is a good fit and there exist a serial correlation in the model.

Therefore, one of the findings of this study is that the Nigerian import affect foreign exchange rate in Nigeria from 1986 to 2016. Another finding of this study is that the Nigerian export does not affect foreign exchange rate in Nigeria from 1986 to 2016. We accept the null hypothesis and reject the alternative hypothesis that the Nigeria export trade does not affect foreign exchange rate. Therefore, one of the findings of this study is that the Nigeria export does not affect foreign exchange rate in Nigeria. Having noted that export is a part of the terms of trade or balance of payment and which a determinant factor of foreign exchange rate. The reason for this study where the export (EXPT) does not affect the foreign exchange rate (FX) may arise as a result of low level capacity of the local production. This study therefore confirms Nigeria as a country of more import than export thereby weakening her foreign exchange capacity and declining her external reserves. The findings of this study reaffirms the study of Eliza et al (2008) which stated that current account balance such as the use of import and export have affect external reserves in Malaysia between 1970 to 2004. 


\section{References}

Ajibola, I.O et-al.(2015) Nonlinear Adjustments between Exchange Rates and External Reserves in Nigeria: A Threshold Co-integration Analysis. CBN Journal of Applied Statistics. 6 (1), 73-11.

Ana Maria Romero (2005). Comparative Study: Factors that Affect Foreign Currency Reserves in China and India. Honors Research, Economics Department Spring 2005, Illinois Wesleyan University.

Central Bank of Nigeria. July 2017 Website. www.cbn.gov.ng

Cushman, D.O. (1988). Exchange Rate Uncertainty and Foreign Direct Investment in the United States, Weltwirtschaftliches Archiv 124(2), 322-334.

Daud, S. N. M and A.H. Ahmed. (2013). The Cost of International Reserves: An Empirical from Malaysia. Journal of Economic Cooperation and Development, 34(4), 23-46.

Dooley, M. P., Folkerts-Landau, D. and Garber, P. (2004), The revived Bretton Woods system. Int. J. Fin. Econ., 9(1), 307-313.

Eliza, N and Azali M. and Siong-Hook Law and Chin Lee (2008): Demand For International Reserves in ASEAN-5 Economies. Universiti Putra Malaysia.

Ellahi N, Ahmad M (2011). Testing the Joint Impact of Foreign Aid and Foreign Direct Investment on Overtime Economic Growth of Pakistan. International Conference on Business and Economic Research. Langkawi Malaysia: World Research Agency.

Esther O. Adegbite \& Folorunso. S. Ayadi, (2011), The role of foreign direct investment in economic development: A study of Nigeria, 6(1/2), 133-147. World Journal of Entrepreneurship, Management and Sustainable Development.

Georgoulias, K., Papakostas, N., Chryssolouris, G., Stanev, S., Krappe, H. and Ovtcharova, J. (2009). Evaluation of flexibility for the effective change management of manufacturing organizations. Robotics and ComputerIntegrated Manufacturing, 25(6), 888-893.

Gokhale, M.S. and R. Raju (2013). Causality between Exchange Rate and Foreign Exchange. Global Journal of Management and Business Research, 13(7), 1-12.

Guglielmo Maria Caporale, Faek Menla Ali, Fabio Spagnolo and Nicola Spagnolo (2013), International Portfolio Flows and Exchange Rate Volatility for Emerging Markets. German Institute for Economic Research. 3, 567-588.

Hamen, Harley T.W. \& Abiodun $O$ (2014). The Impact of Global Financial Crisis on Economy Growth on a Developing Economy. (An Instrumental Variable Regression Approach). Global Advance Journal of Business and Management, 3(1).

Harley Tega Williams, Iriyemi Ademola \& Dare Adegbola (2018). An Empirical Analysis of the Impact of Private Port Operators in International Trade Development. SIREN Journal. University of Port Harcourt Journal of Business, Accounting and Finance Management, 8(1), 256-277.

Kiru Sichoongwe (2016). Effects of Exchange Rate Volatility on the Stock Market: The Zambian Experience. Journal of Economics and Sustainable Development. 7(4), 114-119.

Kyereboah-Coleman, A. and Agyire-Tettey, K.F. (2008). Effect of Exchange-Rate Volatility on Foreign Direct Investment in Sub-Saharan Africa: The Case of Ghana (Case study). Journal of Risk Finance, 9(1), 52 -70.

Lazarus Ajim. (2017), Impact of Foreign Direct Investment on Power Sector of Nigeria, Journal of Management Research, 5 (3), 63-80.

Ngozi E. Nwachukwu, Abdulkadir I. Ali, Ismaila S. Abdullahi, Mohammed A. Shettima, Solomon S. Zirra, Bola S. Falade, and Michael J. Alenyi (2016). Exchange Rate and External Reserves in Nigeria: A Threshold Cointegration Analysis. 7(1), 233-245. CBN Journal of Applied Statistics. 9, 123-131

Odili Okochukwu (2015). Exchange Rate Volatility, Stock Market Performance and Foreign Direct Investment in Nigeria. International Journal of Academic Research in Accounting, Finance and Management Sciences. 5(2), 3449.

Osinubi, T.S. and Amaghionyeodiwe, L.A. (2009). Foreign Direct Investment and Exchange Rate Volatility in Nigeria, International Journal of Applied Econometrics and Quantitative Studies, 6 (2): 84-115.

Owolabi, F. Ojibe. (2017), Exchange Rate Volatility, Inflation Uncertainty and Foreign Direct Investment in Nigeria. Botswana Journal of Economics, 5(7), 14-31. 
Schumpeter, J.A. (1911). The Theory of Economic Development. Harvard University Press, Cambridge.

Tariq, M., Z. Haq, S. Jan, M. Jehangir, and M. Aamir. (2014). Real Exchange Rate and Foreign Exhange reserves: A Mercantilist View. Life Science Journal, 11(3s), 121-134

Yousaf, S., Shahzadi, I., Kanwal, B. and Hassan, M. (2013), Impact of Exchange Rate Volatility on FDI in Pakistan. IOSR J. Bus. Management, 12(1): 79-86.

Unpublished dissertation on the Determinants of Foreign Direct Investment in Nigeria. 